\title{
Trade, Environment and Economic Development: A Dynamic Relationship in East Asia
}

\author{
Jingjing Zhang
}

\begin{abstract}
This study investigates the dynamic relationship between trade, environment and economic development in East Asia. Empirical analysis based on panel cointegration technique suggests that there is a long-run stable relationship among economic development, trade and environmental pollution in East Asia. In order to examine the role of the level of economic development, the sample is extended to include some major world economies. The extended sample was then divided into three groups: East Asia, developed countries and developing countries. The estimated results based on panel VAR suggest the presence of interrelationship among all variables in each of three country-groups. The impulse response analysis reveals that shocks to economic development and trade in developing countries lead to a large increase in pollution. However, in the case of developed countries, an increase in GDP results in a decrease in pollution. We find that the level of economic development plays a crucial part in determining the direction of the interrelationship among trade, environment and economic growth.
\end{abstract}

Index Terms-International trade, environment, economic development, panel VAR.

\section{INTRODUCTION}

The level of public awareness concerning the implications of human-activities-related environment degradation and climate change has significantly increased in recent decades. As a result of this growing awareness, a vast literature that deals with the relationship between economic development and environment has emerged. The early work of [1] provided the most comprehensive review on the relationship between economics and environment in a general equilibrium setting. Their research reveals that, due to the presence of diminishing marginal return on environmental resources, the use of environmental resources in production first increases. However, once the economy reaches a certain critical level of development, the use of environmental resources in production declines. In other words, there is an inverted U-shaped relationship between income and environmental degradation. The relationship between income and environmental degradation is also known as the Environmental Kuznets Curve (EKC). Ref. [2]'s empirical study supports the idea of an inverted U-shape relationship between income and environmental degradation. While the link between pollution and economic development is generally backed up by a large number of studies that cover many countries, the issue of what measures of pollution (i.e., deferent types of pollutants) to use in such is far from settled.

Manuscript received May 24, 2014; revised July 22, 2014.

Jingjing Zhang is with the University of Western Sydney, School of Business, NSW 2751, Australia (e-mail:njustzjj@gmail.com).
The use of different pollutants can leads to different empirical results. For example, while considering the case of China, [3] used five different types of pollutants. Using a simultaneous equations model, [3] found that empirical results concerning the link between economic growth and pollution vary vastly cross the type of pollutant used. Ref. [3]'s work highlights alternative policy instruments in use on environmental issue. Ref. [4] used a semi-parametric approach to test the EKC hypothesis. Their work is based on cross-city data from the US for 1990. In their non-parametric/semi-parametric model, model specification is mainly determined by data, instead of being imposed ad hoc prior. Related studies include [5]-[8].

The debate over economic development and change in environment has coincided with vigorous debate on the environmental consequences of globalization. WTO's special study on 'Trade and Environment' suggests that environmental degradation is caused by (i) chemical intensive agriculture, (ii) deforestation, (iii) global warming, (iv) acid rain, and (v) overfishing ([9]). It is argued that though international trade is not the direct cause of environmental degradation, international trade can sometimes exacerbate the effects of poor policy and market failure. To investigate the linkage between trade and pollution, [10] empirically studied the impact of North America Free Trade Agreement (NAFTA) on environment. They decomposed the effect of trade on environment into scale, composition and technique effects. In a series of subsequent studies, [11], [12] developed a theoretical model that deals with the interaction of scale, composition and technique effects associated with trade and pollution. More recent studies have attempted to investigate the trade-environment link issue by making use of multi-country data and more advanced statistical techniques. Using an instrumental variable (IV) based estimation technique, [13] examined the impact of openness on environmental quality. As trade and income as endogenous variables, the use of an IV based estimation technique is highly appropriate. Similar study, such as [14]-[16], found different environmental effects of international trade, by empirical testing different pollutants.

While a large number of existing studies have focused on the link between economic development and environment as well as economic development and trade, few studies have investigated the interrelationship between international trade, economic development, and environmental pollution in a dynamic setting. ${ }^{1}$ The purpose of this study is to explore the dynamic relationship between trade, environment and

\footnotetext{
1 The existing studies that deal economic growth, trade and environment include [17]-[19].
} 
economic development in the context of East Asia and some other major world economies.

This paper is organized as follows. Section I includes the study background and a brief literature review. Data and procedures used to investigate the dynamic relationship among trade, economic development and environmental change is discussed in Section II. Empirical results are presented and discussed in Section III. Section IV contains some concluding remarks.

\section{MethodS AND DATA}

\section{A. Specification of Empirical Model}

Based on the existing literature, it is conjectured that trade has contributed to economic growth through globalization. At the same time, increased trade has implications for the environment. Increase in international trade almost always involves increase in production. An increase in production can result in higher level of pollution. In other words, increased trade has resulted in higher demand for environmental resources. ${ }^{2}$ At the same time, increase in household income, due to economic growth, has also resulted in requirement for better environmental quality. Environmental resource, like other inputs (such as labour and capital) has been widely recognized as a critical input that could cause comparative advantage in international competition.

In order to investigate the dynamic linkage between economic development, international trade and environment, in this study, we use panel Vector Auto Regression (VAR) approach. This methodology also allows one to examine the extent of independencies among time-varying variables in a panel setting.

In panel VAR model, trade, economic development and environment are treated as endogenous variables. The right hand side variables in VAR setting as shown in equations 1(a) to 1(c) include lagged values of both the right hand and the left hand side variables.

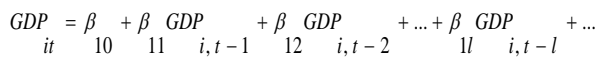

$$
\begin{aligned}
& \ldots+\beta_{1 l+1} \text { trade } i, t-1+\beta_{1 l+2} \text { trade } i, t-2+\ldots+\beta_{1 l+l} \text { trade }_{i, t-l}+\ldots
\end{aligned}
$$

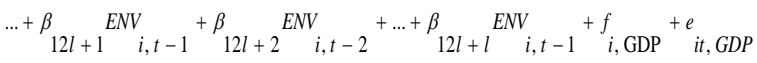

$$
\begin{aligned}
& \text { trade }_{i t}=\beta_{20}+\beta_{21} G D P_{i, t-1}+\beta_{22} G D P_{i, t-2}+\ldots+\beta_{2 l} G D P_{i, t-1}+\ldots \\
& \ldots+\beta_{2 l+1} \operatorname{trade}_{i, t-1}+\beta_{2 l+2} \text { trade }_{i, t-2}+\ldots+\beta_{2 l+l} \text { trade }_{i, t-l}+\ldots \\
& \ldots+\beta_{22 l+1} E N V_{i, t-1}+\beta_{22 l+2} E N V_{i, t-2}+\ldots+\beta_{22 l+1} E N V_{i, t-1}+f_{i, t \text { rude }}+e_{i t, \text { trade }}
\end{aligned}
$$

$$
\begin{aligned}
E N V_{i t}= & \beta_{30}+\beta_{31} G D P_{i, t-1}+\beta_{32} G D P_{i, t-2}+\ldots+\beta_{3 l} G D P_{i, t-l}+\ldots \\
& \ldots+\beta_{3 l+1} \operatorname{trade}_{i, t-1}+\beta_{3 l+2} \operatorname{trade}_{i, t-2}+\ldots+\beta_{3 l+l} \operatorname{trade}_{i, t-l}+\ldots \\
& \ldots+\beta_{3 l+1} E N V_{i, t-1}+\beta_{32 l+2} E N V_{i, t-2}+\ldots+\beta_{32 l+l} E N V_{i, t-1}+f_{i, E N V}+e_{i t, E N V}
\end{aligned}
$$

\footnotetext{
${ }^{2}$ In this study, we use pollution as a measure environmental resources.
}

where $i$ represents the index of section (country); $t$ represents time (year); $l$ is the longest lag period; GDP is the gross domestic product; trade is a measure of international trade; ENV is a measure of environmental resource; $\beta$ are the unknown population parameters; $f$ captures the sectoral fixed effects; and $e_{i t}$ is the error term which captures the impact of all omitted variables.

As shown in equation 1(a) to 1(c), each of the three variables is affected by its own lagged values as well as the lagged values of other endogenous variables. The above three equations model can also be viewed as a reduced form model. One of the most important assumptions, in panel data regression, is that the structure across sections remains fixed. Following, [20], [21], in this study we use mean-differencing approach to remove the forward mean (i.e., the mean of all of the future observations for each country in every year to assure the individual effect is eliminated and same-structure assumption is not violated)

\section{B. Data and Descriptive Statistics}

\begin{tabular}{ccc}
\multicolumn{3}{c}{ TABLE I: COUNTRIES CLASSIFICATION } \\
\hline $\begin{array}{l}\text { Group 1: East } \\
\text { Asia }\end{array}$ & $\begin{array}{l}\text { Group 2: } \\
\text { Developed }\end{array}$ & $\begin{array}{l}\text { Group 3: } \\
\text { Developing }\end{array}$ \\
\hline China & Japan & China \\
Japan & Korea & India \\
Korea & Singapore & Indonesia \\
Indonesia & USA & Malaysia \\
Malaysia & Australia & Thailand \\
Thailand & Euro area & Vietnam \\
Singapore & & Philippines \\
Vietnam & & \\
Philippines & & \\
\hline
\end{tabular}

TABLE II: SUMMARY STATISTICS OF THE COUNTRY GROUPS

\begin{tabular}{lcrrrr}
\hline Variable & Obs & Mean & $\begin{array}{l}\text { Std. } \\
\text { Dev. }\end{array}$ & Min & \multicolumn{1}{l}{ Max } \\
\hline \multicolumn{6}{c}{ East Asia } \\
GDP & 453 & 25.550 & 1.691 & 22.053 & 29.189 \\
Trade & 413 & 25.131 & 1.548 & 21.097 & 28.716 \\
$\mathrm{CO}_{2}$ & 449 & 11.551 & 1.7671 & 6.5141 & 15.930 \\
\hline \multicolumn{7}{c}{ Developed economies } \\
GDP & 318 & 27.443 & 2.0899 & 22.053 & 30.235 \\
Trade & 291 & 26.507 & 1.822 & 21.097 & 29.855 \\
$\mathrm{CO}_{2}$ & 306 & 12.958 & 1.948 & 6.514 & 15.578 \\
\hline
\end{tabular}

Developing economies

\begin{tabular}{lrrrrr} 
GDP & 347 & 25.328 & 1.3027 & 22.618 & 29.140 \\
Trade & 323 & 24.758 & 1.357 & 22.167 & 28.716 \\
$\mathrm{CO}_{2}$ & 347 & 11.660 & 1.7443 & 7.344 & 15.930 \\
\hline
\end{tabular}

Source: World Databank. GDP (2005 constant USD), trade (M+I in goods and service, 2005 constant USD), $\mathrm{CO}_{2}(\mathrm{kt})$. All data are in logarithmic form

In order to estimate the reduced form model as shown in 1(a) to 1(c), GDP (in constant US dollar values) is used as a measure of economic development, $\mathrm{CO}_{2}$ emission is used as proxy for environmental quality and the sum of import and export (in constant US dollar values) measures the level of international trade. Data are collected from the World 
Databank - the World Development Indicators (World Bank dataset). While the focus of this study is on East Asia, for the comparison purposes, data from some major non-East Asian developed and developing economies is also utilized. The classification criteria used in this study is based on the definition of World Bank - i.e., Countries with GNP per capita higher than US\$12,616 in 2012 are classified as developed countries. The country groups are shown in Table I.

In this study, we use logarithmic forms of all endogenous variables. The logarithmic form is used for two reasons: (i) the estimated population coefficients can be interpreted as elasticity and (ii) as the panels include heterogeneous countries and we use absolute values of all the variables that vary considerably across countries, logarithmic reduces the scale effect. The summary statistics of the logarithmic variables is presented in Table II.

\section{EMPIRICAL ESTIMATION AND DISCUSSION}

\section{A. Stationarity Test}

It is widely recognized that econometric analysis based on non-stationary time series could lead to the problem of spurious regression ([22]-[24]). In order to avoid this problem, we need to test for stationarity of variables before we estimate the dynamic relationship among the three endogenous variables. Unlike the times series data that consists of only one section, panel data allows for the sections to have different individual effects.

Before estimating the empirical model, we test for both the common unit root and individual unit root. The results of panel unit root testing are reported in Table III.

The results reported in Table III suggest that GDP and Trade are non-stationary in levels but the first differences are stationary. However, in the case of $\mathrm{CO}_{2}$, four out of five tests suggest non-stationarity in the level variable but the first differences are stationary. In the case of unbalanced panel data with potential individual unit root process, ADF-Fisher Chi-square could be the best fitted approach since it conducts unit root test for each panel individually. The ADF-Fisher results show that the unit root process exists in all of the three variables. In other words, all of the three variables are non-stationary in levels. As all variables appear to be non-stationary in levels but stationary in first differences, econometric theory suggests testing for the presence of panel cointegration. The presence of panel cointegration implies the presence of a long-run relationship among development, trade and pollution. The results of Johansen-Fisher panel cointegration test are presented in Table IV.

TABLE III: PANEL UNIT ROOT TESTING

\begin{tabular}{|c|c|c|c|c|}
\hline \multirow[b]{3}{*}{ Method } & \multicolumn{4}{|c|}{ GDP } \\
\hline & \multicolumn{2}{|c|}{ Level } & \multicolumn{2}{|c|}{ First difference } \\
\hline & Statistic & Prob. & Statistic & Prob. \\
\hline \multicolumn{5}{|c|}{ Null: Unit root (assumes common unit root process) } \\
\hline Levin, Lin \& Chu t* & -0.714 & 0.238 & -17.329 & 0.000 \\
\hline Breitung t-stat & 4.1346 & 1.000 & -7.495 & 0.000 \\
\hline \multicolumn{5}{|c|}{ Null: Unit root (assumes individual unit root process) } \\
\hline Im, Pesaran and Shin W-stat & 2.475 & 0.993 & -15.753 & 0.000 \\
\hline ADF - Fisher Chi-square & 14.240 & 0.970 & 245.520 & 0.000 \\
\hline \multirow[t]{3}{*}{ PP - Fisher Chi-square } & 28.9894 & 0.312 & 241.085 & 0.000 \\
\hline & \multicolumn{4}{|c|}{ Trade } \\
\hline & \multicolumn{2}{|c|}{ Level } & \multicolumn{2}{|c|}{ First difference } \\
\hline \multicolumn{5}{|c|}{ Null: Unit root (assumes common unit root process) } \\
\hline Levin, Lin \& Chu $\mathrm{t}^{*}$ & -0.029 & 0.489 & -20.986 & 0.000 \\
\hline Breitung t-stat & 3.122 & 0.999 & -13.857 & 0.000 \\
\hline \multicolumn{5}{|c|}{ Null: Unit root (assumes individual unit root process) } \\
\hline Im, Pesaran and Shin W-stat & 2.418 & 0.992 & -18.392 & 0.000 \\
\hline ADF - Fisher Chi-square & 9.567 & 0.999 & 282.873 & 0.000 \\
\hline \multirow[t]{3}{*}{ PP - Fisher Chi-square } & 12.237 & 0.990 & 299.721 & 0.000 \\
\hline & \multicolumn{4}{|c|}{$\mathrm{CO}_{2}$} \\
\hline & \multicolumn{2}{|c|}{ Level } & \multicolumn{2}{|c|}{ First difference } \\
\hline \multicolumn{5}{|c|}{ Null: Unit root (assumes common unit root process) } \\
\hline Levin, Lin \& Chu $\mathrm{t}^{*}$ & -3.341 & 0.000 & -19.017 & 0.000 \\
\hline Breitung t-stat & 4.463 & 1.000 & -7.817 & 0.000 \\
\hline \multicolumn{5}{|c|}{ Null: Unit root (assumes individual unit root process) } \\
\hline Im, Pesaran and Shin W-stat & -0.1876 & 0.426 & -19.462 & 0.000 \\
\hline ADF - Fisher Chi-square & 25.958 & 0.465 & 305.821 & 0.000 \\
\hline PP - Fisher Chi-square & 27.401 & 0.389 & 351.197 & 0.000 \\
\hline
\end{tabular}

The results of Johansen-Fisher panel cointegration test suggest that the hypothesis of no cointegration should be rejected. Therefore, it is conjectured that though economic development, trade and $\mathrm{CO}_{2}$ pollution are all non-stationary, these three variables are connected though a common stochastic trend. 
TABLE IV: JOHANSEN-FISHER PANEL COINTEGRATION TEST Series: GDP TRADE $\mathrm{CO}_{2}$

Sample: 19602012

Trend assumption: Linear deterministic trend (restricted)

Lags interval (in first differences): 01

\begin{tabular}{lllll}
\hline $\begin{array}{l}\text { Hypothesized } \\
\text { No. of CE(s) }\end{array}$ & $\begin{array}{l}\text { Fisher Stat. } \\
\text { (from trace } \\
\text { test) }\end{array}$ & Prob. & $\begin{array}{l}\text { Fisher Stat. } \\
\text { (from max-eigen } \\
\text { test) }\end{array}$ & Prob. \\
None & 111.1 & 0.000 & 109.3 & 0.000 \\
At most 1 & 21.31 & 0.726 & 25.35 & 0.499 \\
At most 2 & 8.594 & 1.000 & 8.594 & 1.000 \\
\hline
\end{tabular}

Note: Probabilities are computed using asymptotic Chi-square distribution.

\section{B. Panel VAR Estimation}

The main objective of this study is to test for the presence of a dynamic relationship among economic development, international trade and $\mathrm{CO}_{2}$ pollution. The empirical specification, i.e., equations (1a) to (1c) assume that both economic and environmental variables are partly determined by their past values and also have impacts on the own performance in the future. At the same time, a dynamic system that is characterized by interacted effects - i.e., the past values of one factor could affect other factors in the future. It is widely believed that trade affects economic development and change in the level of pollution is mainly caused by economic development. To test for the presence of these dynamic effects, we use the panel VAR. In order to take in to account the impact of the differences in the level of economic development, the dataset has been divided into three groups. The three groups as selected East Asian economies (EA), selected Developed Economies and selected Developing Economies. The hypotheses being tested are as follows: (i) the dynamic relationship among trade, development and pollution varies across the level of economic development, and (ii) all country groups follow the same developmental trajectory. Panel VAR regression results are presented in Table $\mathrm{V}$.

\begin{tabular}{|c|c|c|c|c|c|}
\hline \multicolumn{2}{|l|}{ EA economies } & \multicolumn{2}{|c|}{ Developed economies } & \multicolumn{2}{|c|}{ Developing economies } \\
\hline \multicolumn{6}{|c|}{ EQ1: dep.var GDP } \\
\hline L.GDP & $0.919 * * *$ & L.GDP & $0.973 * * *$ & L.GDP & $0.761 * * *$ \\
\hline L.Trade & -0.009 & L.Trade & -0.022 & L.Trade & $0.114 * * *$ \\
\hline L. $\mathrm{CO}_{2}$ & $0.057 * *$ & L. $\mathrm{CO}_{2}$ & $0.032 * * *$ & L. $\mathrm{CO}_{2}$ & $0.032 *$ \\
\hline
\end{tabular}

EQ2: dep.var Trade

\begin{tabular}{|c|c|c|c|c|c|}
\hline L.GDP & -0.082 & L.GDP & -0.025 & L.GDP & $-0.364 * * *$ \\
\hline L.Trade & $0.973 * * *$ & L.Trade & $0.955^{* * *} *$ & L.Trade & $1.190 * * *$ \\
\hline L.CO ${ }_{2}$ & 0.063 & L. $\mathrm{CO}_{2}$ & $0.042 *$ & L. $\mathrm{CO}_{2}$ & 0.031 \\
\hline
\end{tabular}

EQ3: dep.var $\mathrm{CO}_{2}$

\begin{tabular}{llllll} 
L.GDP & -0.061 & L.GDP & -0.034 & L.GDP & $-0.233 * * *$ \\
L.Trade & 0.022 & L.Trade & 0.006 & L.Trade & $0.148 * * *$ \\
L.CO ${ }_{2}$ & $0.974 * * *$ & L.CO $_{2}$ & $0.966 * * *$ & L.CO $_{2}$ & $0.967 * * *$ \\
\hline Note: Symbol L. indicates one order lag. All variables are in logarithms.
\end{tabular}

Table $\mathrm{V}$ shows that GDP, trade and the level of $\mathrm{CO}_{2}$ emission demonstrate significant auto-regressive trend. The last year's GDP has a significant and positive impact on the current year's GDP. Comparing the three groups, it can be argued that developed countries have strong auto-regression effect in terms of GDP, followed by East Asia countries, and the developing economies. In contrast, trade of developing countries shows a stronger time-effect compared to East Asian and developed economies. The pollution variable demonstrates a similar trend.

While the auto-regression results demonstrate a fairly similar pattern, the analysis of the interaction effect reveals some interesting differences among the three groups. Table V shows that the impact of last year's trade on current year's GDP of developing countries but such pattern is observed neither in developed nor in East Asia country groups. However, the impact of $\mathrm{CO}_{2}$ on GDP is significant across each of the three country groups. Comparing the regression coefficient of variables in logarithm, East Asia economies have a higher elasticity of current economic development with respect to past pollution.
The estimated results concerning the impact of pollution on trade contain some counter-intuitive results. The unique group that presents the significant influence of pollution on trade is developed countries. While the notion that loose environmental policy generated comparative advantage in trade to developing countries is largely discarded, the empirical results presented in this paper do not support this conjecture.

The results regarding the determinants of $\mathrm{CO}_{2}$ emission reveal a different story. The results presented in Table $\mathrm{V}$ suggest that both GDP and trade have insignificant impact on pollution in East Asian and developed country groups. In the case of the developing country group, both economic development and trade impact on environment significantly. While, the GDP has a negative impact on $\mathrm{CO}_{2}$ pollution and trade, the impact of trade on pollution is positive. The former could be explained by means of the EKC hypothesis. As income grows, due to economic development, demand for cleaner environment increases. The latter trend could be explained by the observed increase in demand for environmental resources as economies growth and volume of 
trade increases.

\section{Impulse Response Analysis}

The main purpose of using the VAR approach is to examine the dynamic interaction among variables of interest. To trace out the dynamic responses of endogenous variables in the economic system with respect to a set of identified shocks over time, Impulse Response Function (IRF) is estimated. Fig. 1(a)- Fig. 1(c) present the impulse response of GDP, trade and $\mathrm{CO}_{2}$ to one standard derivation shock in each of the three endogenous variables of different countries groups. The first row of each figure shows the response of GDP to the three different shocks, the second row of each figure shows the response of trade to the three different shocks, and the third row shows the response of $\mathrm{CO}_{2}$. The upper and lower boundaries show the interval estimation at the $5 \%$ level of significance.
The IRF graphs show that the response of GDP to innovation itself decreases smoothly. The series of trade and $\mathrm{CO}_{2}$ demonstrate the similar trend. The response of GDP to innovations in trade and $\mathrm{CO}_{2}$ is generally weak, considering GDP series have strong auto-regression feature. The response of trade to the shock in GDP and $\mathrm{CO}_{2}$ decreases in the case of East Asian and developed economies but it increases in the case of developing economies. There are noticeable differences in the response of $\mathrm{CO}_{2}$ to shock to GDP and trade across developed and developing countries. While a positive shock to GDP leads to a decrease in $\mathrm{CO}_{2}$ in developed countries, the response of $\mathrm{CO}_{2}$ in the case of developing countries is almost constant. In contrast, in the case of developing countries, a positive shock to GDP leads to an increase in $\mathrm{CO}_{2}$ and a positive shock to trade has a similar effect on $\mathrm{CO}_{2}$ in developing countries.

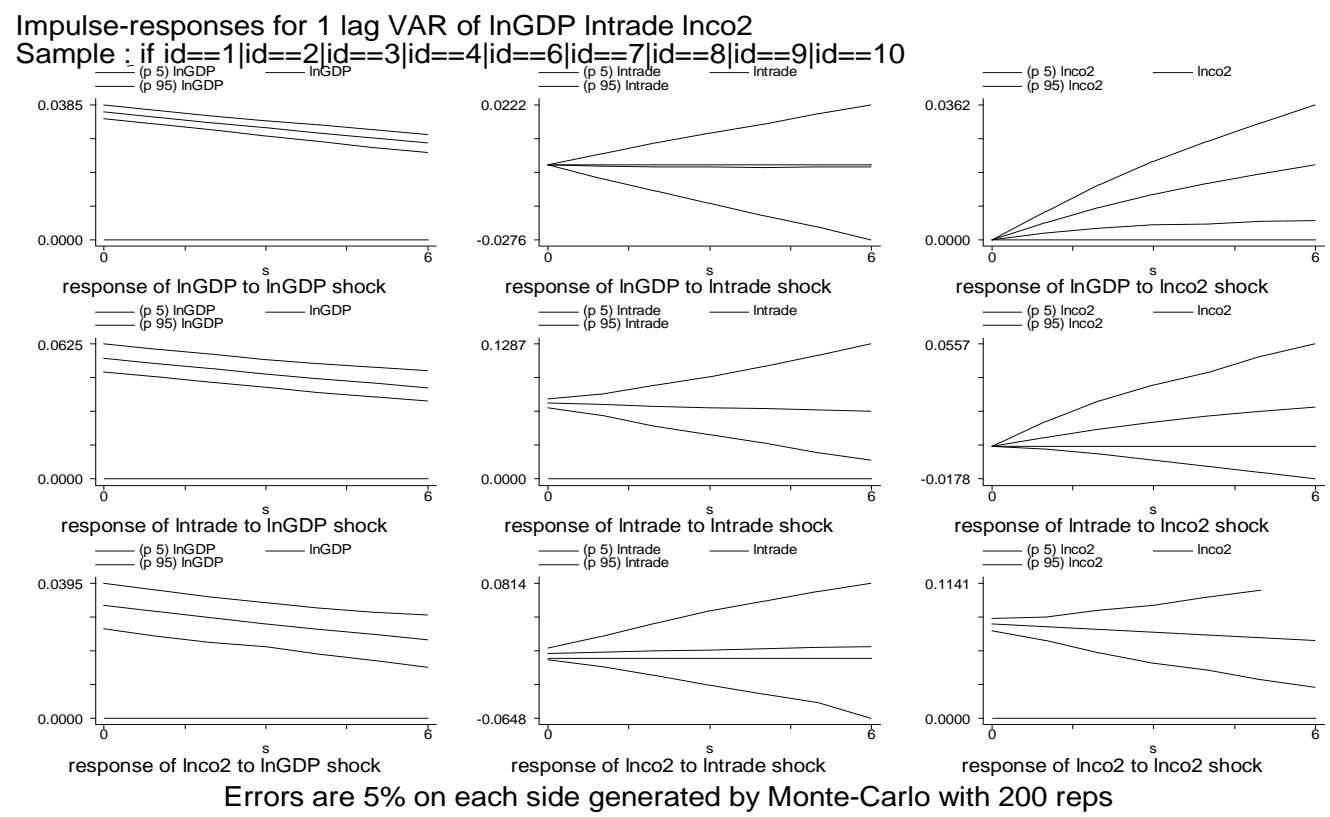

Fig. 1(a). Impulse responses for East Asia countries.

Impulse-responses for 1 lag VAR of InGDP Intrade Inco2 Sample : if id $==2 \mid$ id $==3 \mid$ id $==7 \mid$ id $==11 \mid$ id $==12 \mid$ id $==15$
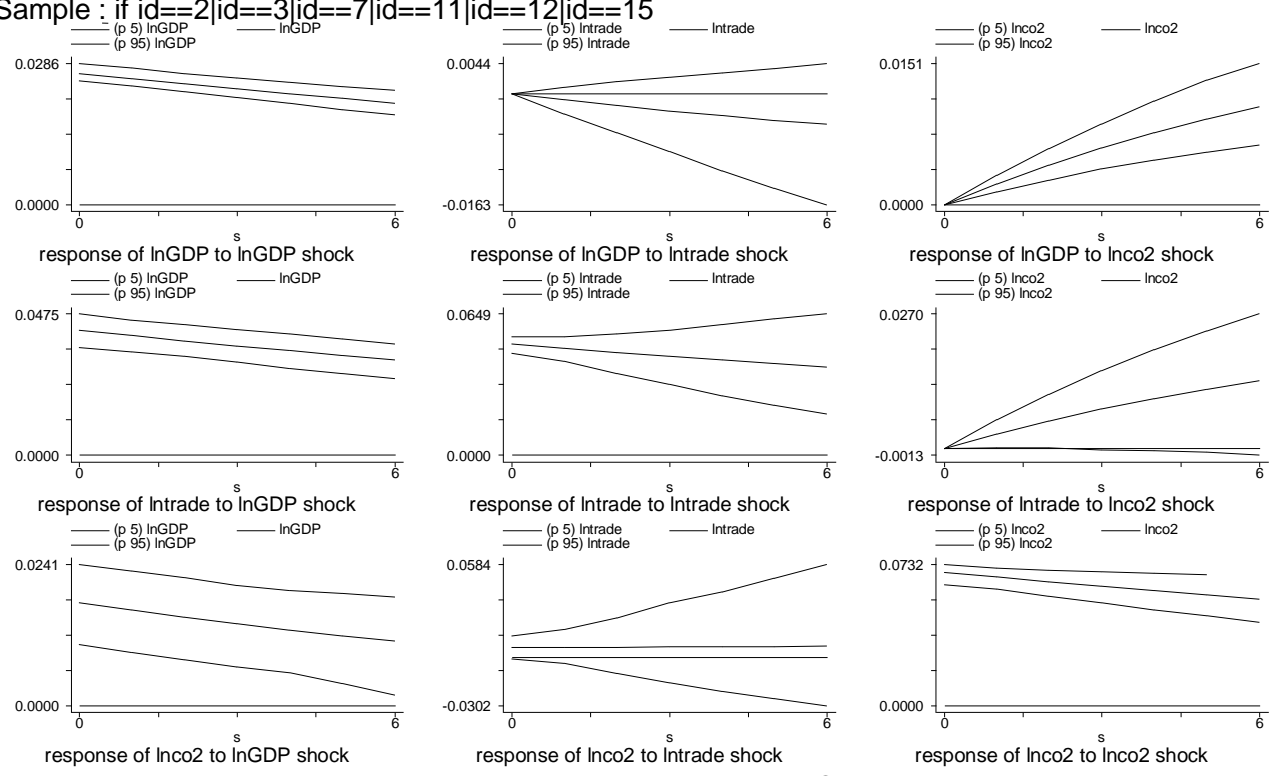

Errors are $5 \%$ on each side generated by Monte-Carlo with 200 reps

Fig. 1(b). Impulse responses for developed countries. 


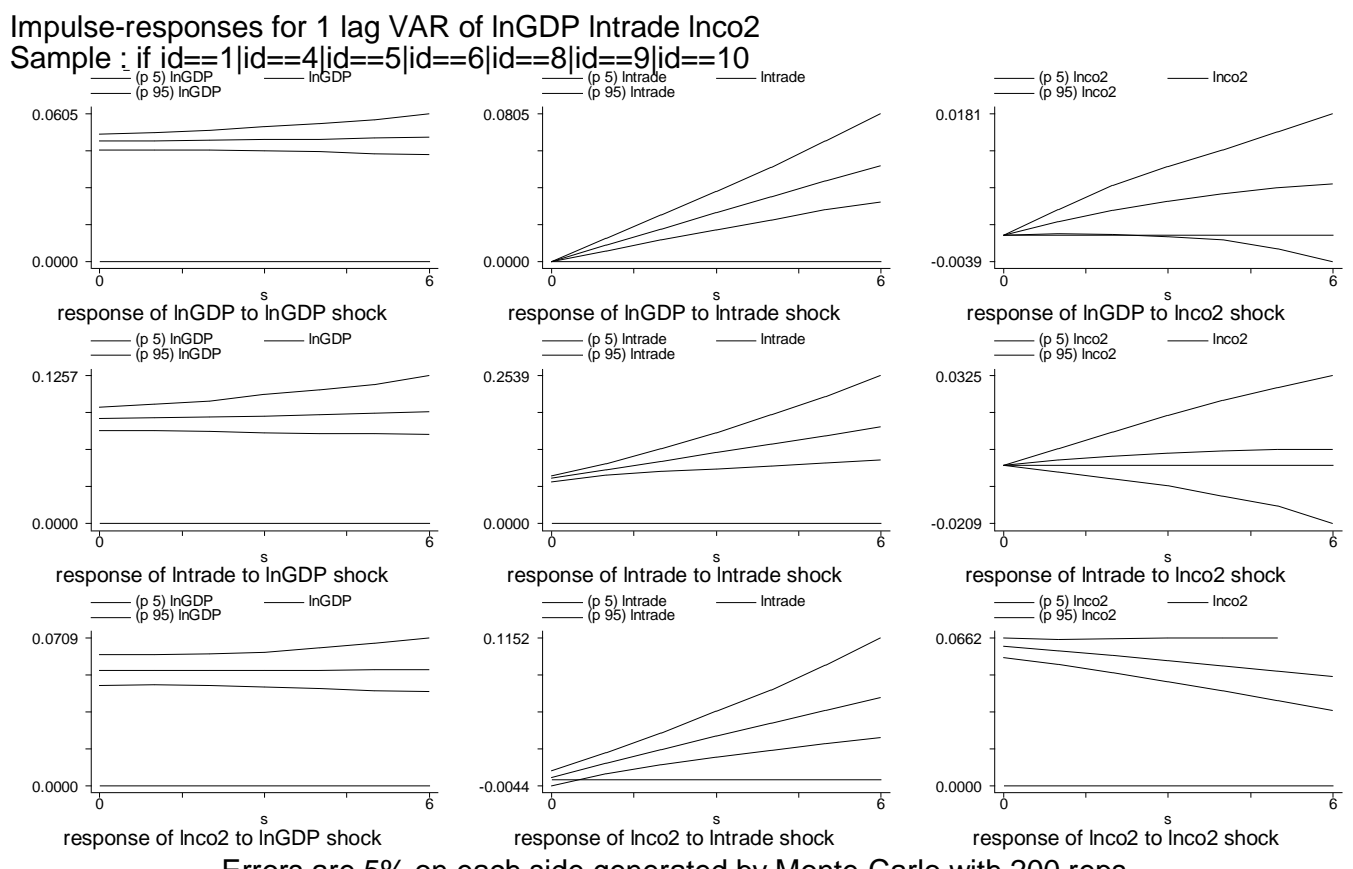

Errors are $5 \%$ on each side generated by Monte-Carlo with 200 reps

Fig. 1(c). Impulse responses for developing countries.

Fig. 1. Impulse response analysis. The country id: 1=China, 2=Japan, 3=Korea, 4=Indonesia, 5=India, 6= Malaysia, 7=Singapore, 8=Thailand, 9=Vietnam, $10=$ Philippines, $11=$ United States, 12= Australia, and 15=Euro area.

\section{Variance Decomposition}

Variance decomposition analysis reveals how much of the variance of forecast error is determined by each of the endogenous variables. The results of variance decomposition are presented in Table VI.

\section{TABLE VI: VARIANCE DECOMPOSITION}

\begin{tabular}{ccccc}
\hline \multicolumn{5}{c}{ EA economies } \\
& period & GDP & Trade & $\mathrm{CO}_{2}$ \\
GDP & 10 & 0.762 & 0.000 & 0.237 \\
Trade & 10 & 0.308 & 0.646 & 0.047 \\
$\mathrm{CO}_{2}$ & 10 & 0.120 & 0.023 & 0.857
\end{tabular}

\begin{tabular}{ccccc}
\multicolumn{5}{c}{ Developed economies } \\
& period & GDP & Trade & $\mathrm{CO}_{2}$ \\
GDP & 10 & 0.840 & 0.025 & 0.134 \\
Trade & 10 & 0.375 & 0.584 & 0.041 \\
$\mathrm{CO}_{2}$ & 10 & 0.046 & 0.012 & 0.942
\end{tabular}

\begin{tabular}{ccccc}
\multicolumn{5}{c}{ Developing economies } \\
& period & GDP & Trade & $\mathrm{CO}_{2}$ \\
GDP & 10 & 0.538 & 0.453 & 0.008 \\
Trade & 10 & 0.281 & 0.718 & 0.001 \\
$\mathrm{CO}_{2}$ & 10 & 0.332 & 0.372 & 0.296 \\
\hline
\end{tabular}

The results presented in Table VI suggest that the unexpected change in trade and $\mathrm{CO}_{2}$ has very small effect on the variance of GDP in East Asian group and developed country groups. However, a change in trade has a large effect on GDP of the developing country group. Table VI also shows that, in the group of developing economies, the impact of innovations in trade is stronger on $\mathrm{CO}_{2}$ than the impact caused by innovation in $\mathrm{CO}_{2}$. Conversely, the innovation in $\mathrm{CO}_{2}$ explain most of the variance in itself in East Asian and developed countries groups, rather than other aspects.

\section{CONCLUSIONS}

This study aims to investigate the dynamic interrelationship among economic development, international trade, and environmental pollution in East Asia. We use $\mathrm{CO}_{2}$ emission as a proxy for pollution. Using panel cointegration analysis, we find that there is a stable long-run relationship among the three variables. In order to focus on the role of the level of economic development, the sample is extended to include some major world economies. The extended sample is divided into three groups: East Asia, Developing countries and Developed countries. The empirical analysis based on panel VAR approach suggests the present of significant interrelationship among the three variables in each of the three country groups. Surprisingly, only the group of developed countries shows a significant relationship influence of pollution on trade which rejects the pollution haven hypothesis in the sample. We find that both GDP and trade have insignificant impact on pollution in East Asia and developed country groups. In the case of the developing country group, economic development has significant negative impact on environment, and trade has positive impact on $\mathrm{CO}_{2}$ pollution. The former is consistent with Environmental Kuznets Curve (EKC) hypothesis but the later result suggests that demand for environmental resources increase due to growing production. The empirical results presented in this paper suggest that the level of economic development plays a crucial part in determining the interrelationship among trade, economic development and environmental pollution. 


\section{REFERENCES}

[1] A. V. Kneese and J. L. Sweeney, Handbook of Natural Resource and Energy Economics, Elsevier, vol. 1, 1985.

[2] N. Shafik and S. Bandyopadhyay, Economic Growth and Environmental Quality: Time Series and Cross Country Evidence, vol. 904, World Bank, 1992.

[3] J. Shen, "A simultaneous estimation of environmental Kuznets curve: evidence from China," China Economic Review, vol. 17, no. 4, pp. 383-394, 2006.

[4] N. Roy and G. C. van Kooten, "Another look at the income elasticity of non-point source air pollutants: A semiparametric approach," Economics Letters, vol. 85, no. 1, pp. 17-22, 2004.

[5] W. A. Brock and M. S. Taylor, "Economic growth and the environment: A review of theory and empirics," Handbook of Economic Growth, vol. 1, no. 1749-1821, 2005.

[6] J. He and H. Wang, "Economic structure, development policy and environmental quality: An empirical analysis of environmental Kuznets curves with Chinese municipal data," Ecological Economics, vol. 76, pp. 49-59, 2012.

[7] P. Mitsis, "Is there an environmental Kuznets curve in the carbon dioxide emissions?" University of Cyprus Department of Economics, 2012.

[8] S. Muhammad, A. K. Tiwari, and N. Muhammad, "The effects of financial development, economic growth, coal consumption and trade openness on $\mathrm{CO}<\mathrm{sub}>2</ \mathrm{sub}>$ emissions in South Africa," Energy Policy, vol. 61, pp. 1452-1459, 2013.

[9] N. Hakan and S. Vaughan, World Trade Organisation Special Studies: Trade and Environment, World Trade Organization, 1999.

[10] G. M. Grossman and A. B. Krueger, Environmental Impacts of a North American Free Trade Agreement, National Bureau of Economic Research, 1991.

[11] B. R. Copeland and M. S. Taylor, Trade and the Environment, Princeton University Press Princeton, 2003.

[12] . R. Copeland and M. S. Taylor, "Trade, growth, and the environment," Journal of Economic Literature, pp. 7-71, 2004.

[13] M. Shunsuke, H. Akira, and T. Tetsuya, "Does trade openness improve environmental quality?" Journal of Environmental Economics and Management, vol. 58, no. 3, pp. 346-363, 2009.

[14] J. A. Frankel and A. K. Rose, "Is trade good or bad for the environment? Sorting out the causality," Review of Economics and Statistics, vol. 87, no. 1, pp. 85-91, 2005.
[15] G. P. Peters and E. G. Hertwich, "Pollution embodied in trade: The Norwegian case," Global Environmental Change, vol. 16, no. 4, pp. 379-387, 2006.

[16] M. A. Boutabba, "The impact of financial development, income, energy and trade on carbon emissions: Evidence from the Indian economy," Economic Modelling, vol. 40, pp. 33-41, 2014.

[17] E. Paul, F. Carl, and R. Costanza, "Trade, environment and development: the issues in perspective," Ecological Economics, vol. 9 , no. 1, pp. 1-12, 1994.

[18] M. A. Cole, "Trade, the pollution haven hypothesis and the environmental Kuznets curve: examining the linkages," Ecological economics, vol. 48, no. 1, pp. 71-81, 2004.

[19] A. Awudu and L. Ramcke, "The impact of trade and economic growth on the environment: Revisiting the cross-country evidence," Kiel working paper, 2009.

[20] A. Manuel and B. Olympia, "Another look at the instrumental variable estimation of error-components models," Journal of econometrics, vol. 68 , no. 1 , pp. 29-51, 1995.

[21] L. Inessa, "Financial development and financing constraints International evidence from the structural investment model," Review of Financial studies, vol. 16, no. 3, pp. 765-791, 2003.

[22] R. F. Engle and C. W. J. Granger, "Co-integration and error correction: representation, estimation, and testing," Econometrica: Journal of the Econometric Society, pp. 251-276, 1987.

[23] P. C. B. Phillips, "Understanding spurious regressions in econometrics," Journal of Econometrics, vol. 33, no. 3, pp. 311-340, 1986.

[24] J. M. Wooldridge, Introductory Econometrics: A Modern Approach, Cengage Learning, 2012.

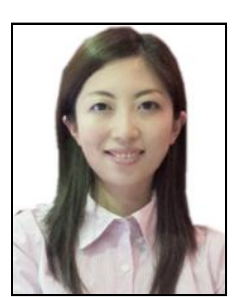

Jingjing Zhang is a Ph.D. candidate of the School of Business at University of Western Sydney. She obtained her BEC degree in 2004 and MEc degree in 2008 at Nanjing University of Science and Technology. Her current research deals with international trade and economics, supply chain management, and relationship between trade and environment. 